\title{
Ssciendo
}

Ethics \& Bioethics (in Central Europe), 2020, 10 (3-4), 203-220

DOI:10.2478/ebce-2020-0019

\section{Freedom in the Society of Control: Ethical challenges}

\author{
Yevhen Laniuk ${ }^{1}$
}

\begin{abstract}
The Society of Control is a philosophical concept developed by Gilles Deleuze in the early 1990s to highlight the transition from Michel Foucault's Disciplinary Society to a new social constitution of power assisted by digital technologies. The Society of Control is organized around switches, which convert data, and, in this way, exercise power. These switches take data inputs (digitized information about individuals) and transform them into outputs (decisions) based on their pre-programmed instructions. I call these switches "automated decision-making algorithms" (ADMAs) and look at ethical issues that arise from their impact on human freedom. I distinguish between negative and positive aspects of freedom and examine the impact of the ADMAs on both. My main argument is that freedom becomes endangered in this new ecosystem of computerized control, which makes individuals powerless in new and unprecedented ways. Finally, I suggest a few ways to recover freedom, while preserving the economic benefits of the ADMAs.
\end{abstract}

Keywords: Freedom, Power, Society of Control, Automated Decision-Making Algorithms, Digital Technologies.

\section{Introduction}

We live in a time of rapidly accelerating computer technologies. Computers have become so deeply entrenched into our lives that we can no longer imagine our societies without them. Some of the greatest achievements of the human mind - from space exploration to decoding DNA - have become possible due to their assistance. However, like atomic energy, this potent technology can do harm if used improperly. Some of the greatest minds in the IT-industry, including Bill Gates and Elon Musk, have warned against the mentality of cyber-utopianism, which regards digital technologies as a universal solution to virtually every human problem and welcomes their unrestrained introduction into society (Sainato, 2015).

Pressing ethical issues arise from the attempts to apply their power to the social realm. Ethical concerns inevitably proceed from the efforts to "digitize" human life, turn it into a stream of data, and make automatic decisions about it using computers. I call the software programs, specifically designed for this purpose "automated decision-making algorithms" (ADMAs) - "automated," because they are inanimate objects, working without human intervention or oversight; "decision-making" - because their rationale is to yield binary decisions, such as "accept / decline," "allow / deny," "pardon / punish," etc.; "algorithms" because they are mathematical models, designed to convert data inputs (digitized information about individuals) into outputs (decisions) in a finite number of steps, based on their preprogrammed instructions. ${ }^{2}$

These ADMAs have become widespread in a wide range of spheres. Banks use them to determine if someone is eligible for a credit or loan; courts - to figure out the risk of recidivism (in some cases, they can even guide the verdict) (O'Neil, 2018, ch. 1); employers - to find out if a prospective employee will be an efficient worker; consumer marketers - to discover the likelihood of purchasing a certain item, etc. As the ecosystem of ADMAs grows, a new type of society is formed around them. Gilles Deleuze theorized about this type of society in his seminal essay Postscript on the Societies of Control (1992), in which he argued that automated switches create a new modality of power, which he called the "Society of Control." The main rationale behind ADMAs is to save money and increase productivity, but they also raise several ethical

\footnotetext{
${ }^{1}$ Ivan Franko National University of Lviv (Ukraine); yevhen.lanyuk@Inu.edu.ua

${ }^{2}$ This approach is close to the concept of "autonomous artificial agents" (AAAs) developed by philosopher Samir Chopra and the attorney Laurence White (Chopra \& White, 2011).
} 
questions: Are these software programs fair? Under what conditions can they be wrong? Which decisions can and cannot be delegated to machines? And, finally, what is the price we must pay for the economic efficiency brought by these ADMAs? Aren't we sacrificing something very important, something that makes us humans, in our ever-growing dependency on the soulless technology, inaugurated by the profit-dominated mind of the capitalist and the cold, calculating mind of the scientist?

It is far beyond the scope of this article to answer these questions. But I would like to raise (and, hopefully, substantiate) one issue here: The ever-growing utilization of ADMAs and the type of society it creates - the Society of Control - tends to push (us) into a world without freedom. These software programs establish invisible bonds that tether individuals to their initial social positions and impede their self-realization. They also tend to create a situation when a person's life is deterministically governed by forces outside his control. Considering their tendency to disproportionately affect the lives of the weak and the poor, they create a dystopian world, in which, in the words of St. Luke, "to everyone who has, more will be given, but as for the one who has nothing, even what they have will be taken away" (Luke 19:26). Such a society is antithetical to the liberal vision, which emphasizes not just the equality of rights, but also the availability of opportunities to fulfill the inalienable human right of the "pursuit of happiness."

The issue of ethical impact of automated decision-making systems on society has been already raised by several authors. Most importantly, by Cathy O'Neil in her book Weapons of math destruction: How big data increases inequality and threatens democracy (O'Neil, 2016), in which she outlines the subversive impact of what she calls "weapons of math destruction" on human society. In Frank Pasquale's book Black box society: the secret algorithms that control money and information (Pasquale, 2016), the author analyzes how the corporate world uses secretive algorithms to control personal behavior and raises a number of political, social, economic, and ethical issues that result from this control. The Harvard University Professor Shoshana Zuboff, in her profound work The age of surveillance capitalism: the fight for a human future at the new frontier of power (Zuboff, 2020), substantiates the concept of "surveillance capitalism" - an economic system that pivots around the commodification of personal data with the purpose of profit-making - and analyzes, among other things, the ethical impact of autonomous decision-making systems. Finally, some general ethical issues related to technological development in the $21^{\text {st }}$ century have been raised by Yuval Noah Harari (Harari, 2016), Nick Bostrom, Francis Fukuyama, Steven Pinker, and many other authors. This article is the first attempt to examine the impact of automated decision-making algorithms on freedom from an ethical perspective specifically in the framework of Gillles Deleuze's concept of the "Society of Control".

It is divided into three parts. In Part 1, I will outline the ethical value of freedom and its manifestation in human society. In Part 2, I will focus on the type of society, which results from a ubiquitous utilization of ADMAs. Following Gilles Deleuze, I will call this type of society "the Society of Control." Hopefully, this will help to establish a theoretical framework, in which, in Part 3, I will examine several ethical challenges to freedom that arise from an increasing application of ADMAs. Finally, in the Conclusion, I will suggest some possible cures.

\section{The ethics of freedom}

Before proceeding to an analysis, it is proper to begin by defining the core concept of this article - freedom. The authoritative Merriam-Webster dictionary of English defines it as: 1. The quality or state of being free: such as: a. the absence of necessity, coercion, or constraint in choice or action, b. liberation from slavery or restraint or from the power of another, c. the quality or state of being exempt or released usually from something onerous, d. unrestricted 
use, e. ease, facility, f. the quality of being frank, open, or outspoken, g. improper familiarity, h. boldness of conception; 2. A political right (Merriam-Webster, Freedom). In the second sense, the word "liberty" is also widely used as a synonym. Two parts of freedom are usually distinguished, namely negative freedom ("freedom from"), which implies the absence of constraints for action, and positive freedom ("freedom to"), or the ability to command control over one's life and realize one's fundamental purposes. Isaiah Berlin conceptualized this distinction in his famous work Four Essays on Liberty (Berlin, 1969), in which he outlined the negative aspect of liberty as the ultimate answer to the question "What is the area within which the subject - a person or group of persons - is or should be left to do or be what he is able to do or be, without interference by other persons?", whereas positive attempts to answer "What, or who, is the source of control or interference that can determine someone to do, or be, this rather than that?" (Berlin, 1969, pp. 121-122). Although Berlin used the term "liberty" in his original essay, I suggest that his two-part typology applies to "freedom." First, this distinction is valid not only in relation to a political authority, but also in social relations more broadly, down to the individual level. Second, in Slavic languages, the differentiation between freedom in general and its political part is usually less pronounced. The title of Berlin's essay is translated as "Dva pojmy slobody" into Slovak, "Dwie koncepcje wolności" into Polish, and “Дві конпепції свободи" [Dvi kontseptsii svobody] into Ukrainian. The Slavic words "sloboda," "wolnośc," and "свобода" [svoboda] are as often used in reference to freedom in general as to the degree of it that one could have in relationships with a political authority.

Freedom and ethics are inextricably connected. On the one hand, freedom is a source of ethics. All ethical systems, including divine command theory, natural law theory, deontological ethics, utilitarianism, contractarianism, etc., assume that the subject of an action toward the Other is free. That action may be subordinate to divine or metaphysical rules, judged by intentions or consequences, but it will be ethically valid only insofar as the one who performs it is free. The Dutch philosopher Bernardo Kastrup argues that freedom is "foundational to our moral codes, criminal justice system, religions and even to the very meaning of life itself" (Kastrup, 2020). On the other hand, freedom is also a purpose of ethics. According to Anatoliy Karas, "ethics is a form and way of activity and an actualization of meeting with the Other," in which "the primacy of the ethical" should be understood "as a priority of the Other in the 'discourse of action' and the realization of individual freedom" (Karas, 2003, p. 408). Aristotle who first used the term "ethics" understood it as "practical wisdom" meant to explain how people should live together and act toward one another as free beings. However, ethics and its principles apply not only to individuals, but to all levels of intersubjective relations, including groups, communities, and society at large.

As both the source and destination of ethics, freedom may not be even interpreted as a value, but as a meta-value, which constitutes the ethical sphere itself, or, rather, the framework of its actualization in human society. At the same time, it is always caught in the "is-ought" dilemma. As Karas argues, "ethics that is not oriented toward the realization of freedom, but simply fixes the existing status quo, does not correspond to the human vocation to care for life and selffulfillment" (Karas, 2003, p. 412). In this article, we will explore the challenges to freedom in the computerized society of the $21^{\text {st }}$ century, or the $i s$, therefore, we should first outline the ought: What is the ethical ideal of freedom and how does it manifest in human society? Since such an analysis can be performed from many theoretical standpoints, we will focus only on the one that fulfills the next three criteria: i. lays the groundwork for the ethical consideration of freedom as a formative ideal of human society; ii. outlines the types of society that are and are not based on this ideal; iii. regards their evolution from a historical perspective. The ethical and political theory by the $19^{\text {th }}$ century Italian philosopher Antonio Rosmini meets all these criteria. 
Similarly to Immanuel Kant, freedom and ethics for Rosmini are inseparably connected and are rooted in the human person. Rosmini defines the person as "a substantial individual in so far as it contains a supreme, incommunicable, intelligent and active principle" (Rosmini, 2010, p. 17). For him, in the perfection of this natural and self-evident principle lies "the moral dignity of persons, their freedom, and that infinite excellence which cedes to nothing and is subservient to nothing" (Rosmini, 2010, p. 19). Dignity, for Rosmini is a counterpart of freedom and is manifested in the person's devotion to truth or Being in its fullness.

Freedom and dignity characterize the domain of persons, as opposed to the domain of things. Rosmini distinguishes between the relationships among persons, which should be grounded on the principles of freedom and dignity, and the relationships of persons with things, which are subject to possession and instrumental use:

\begin{abstract}
The simplest, most general relationships of human beings with things and persons are ultimately those of means and end. Relative to human beings, things are means, persons are ends. From these two fundamental relationships descend all the moral laws which must govern human behavior towards things and persons. The first law, governing human conduct towards things, states: 'Human beings must use things as means to the end proper to human beings.' The second law, governing human conduct towards persons, states: 'Human beings must treat persons as end, that is, as having their own end' (Rosmini, 2010, p. 10).
\end{abstract}

He calls relationships based on the formative principles of freedom and dignity social. "Society presupposes freedom", Rosmini argues. "Persons, as members, are free" (Rosmini, 2010, p. 35). The very task of the social is to increase the scope of human freedom. However, the principle of freedom in relationships among people is oftentimes violated and persons are subjected to the same treatment as things. The philosopher calls these relationships seignioral, and the social order that supports them a seigniory. The seigniory often arises in a situation of conquest and subjugation, when the inhabitants of the conquered country lose freedom, are denied dignity and become mere means to their masters' ends.

In Rosmini's theory, the social and seignioral elements are regarded as ideal types, whereas actual societies combine them in various proportions. History, in his view, consists in the gradual limitation of the latter element and the growth of the former; however, this process is tortuous and has many twists and setbacks. The seignioral element can disappear in one context and then re-appear in another in a totally new form. Though Rosmini elaborated his theory in the $19^{\text {th }}$ century, the seigniory arguably reached its peak a century later. "The formation of such an entity as the society of the Soviet Union," writes Karas, "was completely preceded by its abstract justification as a socio-political means of achieving the Communist goal" (Karas, 2003, p. 291). The question of whether a technologically advanced society of the $21^{\text {st }}$ century can become a new seigniory is open and highly relevant.

The issue of freedom is inseparable from the issue of power. Power is usually seen as an antagonist of freedom, and vice versa. However, such a view is simplistic and only partially correct. The lack of power in society leads to anarchy, not freedom. Freedom is void unless it is protected by some power. Too much power, however, absorbs freedom and leads to tyranny. This dual relationship of power with freedom can be interpreted from the standpoint of Aristotle's distinction of "good" and "bad" types of power. Apart from the issue by whom it was exercised (for Aristotle, it could be one person, a group, or the majority of them), the philosopher argued that "good" power favors its subjects, while "bad" benefits only its carriers at the expense of its subjects. ${ }^{3}$ From this standpoint, freedom simultaneously directs and limits

\footnotetext{
${ }^{3}$ The "good" types, according to Aristotle, were monarchy, aristocracy, and politeia, and the "bad" ones were tyranny, oligarchy, and democracy.
} 
power, constituting the ethical framework of its realization in human society. According to Rosmini, it serves as a criterion of distinction between the seignioral power, which treats the Other as a tool, and social, for which he is an end.

Historically, the government has been seen both as the main protector of freedom and the biggest threat to it. If it did not oppress society, it would be often enough to declare that its members enjoyed negative freedom. Moreover, if it additionally distributed welfare, one could also argue that it provided positive freedom. Democratic institutions, such as political parties, regular elections, governmental checks and balances, etc., have all been established to protect freedom primarily from incursions of the state. However, freedom can be encroached not solely by the government but also by the private sector. The seignioral relationships, which reduce the person to a thing and treat him/her as a pure means to others' ends, can occur beyond the political domain. The early days of industrial capitalism with their extremely harsh working conditions, which allowed Karl Marx to theorize about the "objectification" and "alienation" of workers, may serve as an example. The claim that the threat to freedom could come not only from the government, but from society itself was famously made by John Stuart Mill in his philosophical essay On Liberty:
When society is itself the tyrant ... its means of terrorizing are not restricted to the acts which it may do by the hands of its political functionaries. Society can and does execute its own mandate; and if it issues wrong mandates instead of right, it practices a social tyranny more formidable than many kinds of political oppression, since it leaves fewer means of escape, penetrating much more deeply into the details of life, and enslaving the soul itself (Mill, 1975, p. 6).

The idea that society itself can be a threat to freedom is important for this article, because most of the examples that will be discussed as ethical challenges to freedom involve private companies, not public bodies.

In the modern world, the issue of freedom seems to be at the heart of political and ethical discussions. Apparently, it seems that the Western world lives in the age of profound liberation. Today, the dominant political motive is about "empowerment," giving more rights and opportunities, especially to historically disadvantaged members of society. When I was writing this article, mass protests erupted in the United States and several other countries following the death of an African American man named George Floyd. These protests are not just a reaction to the single act of injustice, but rather a revolt against the social system, in which traditionally dominant social groups allegedly oppress everyone who is outside the white, male-dominated, heterosexual, capitalist culture. The goal of such movements as Black Lives Matter is arguably to overcome the legacy of seigniory, in which members of one race or sex were considered inferior to members of the other and treated more as a means than ends in themselves. But on the other hand, new forms of seigniory seem to emerge, one of which is the ecosystem of computerized regimentation, which the French philosopher Gilles Deleuze conceptualized as the "Society of Control". This environment raises thorny ethical issues, it can potentially curtail freedom and make individuals powerless in new and unprecedented ways.

\section{Ancient aspirations - modern technologies}

In his novel The Pharaoh, the Polish author Boleslaw Prus described a fictional civil war in Ancient Egypt between a young and charismatic pharaoh and a clique of priests, greedy for wealth and political power. The pharaoh had almost defeated the priests on the battlefield, but in the final battle, when his troops were assaulting their last besieged fortress, something mysterious happened. The chief priest appeared on the bulwark, raised his hands to the sky, and the sun began to turn dark. The pharaoh's troops were shocked by his power to command celestial bodies. Seized by a surreptitious fear, they plunged into a panicked stampede and 
almost crushed their commander who vainly tried to hold them back. The soldiers and the pharaoh himself were unaware that the priests were keen on mathematics and astronomy. After centuries of observing the sun, they learned to predict its eclipses, and made the pharaoh assault their fortress on that exact day. Eventually, the priests won the war, despite having been almost defeated on the battlefield.

There are, at least, three things to learn from this episode. First, it illustrates the connection between knowledge and power. Solar eclipses, indeed, occur regularly. With the knowledge of their timing, the priests could predict the future, which gave them an advantage over their superior enemy. Second, it shows that knowledge is profitable only if it is hidden. If it were available also to the pharaoh, his troops, perhaps, would have been less amazed by the priests' trick. Third, it illustrates an unequal society, in which wealth and power are based on some exclusive knowledge available only to the insiders.

Modern societies are supposed to be founded on different principles. They favor democracy over the domination of the few, a strong middle class over the consolidation of money and power in a tiny elite, and a transparency of public institutions over the esoteric concentration of knowledge in closed groups. However, this fictional episode from the $19^{\text {th }}$-century novel seems to highlight precisely the opposite tendency in the development of our technologically advanced societies. Imagine governments, banks, and big tech companies instead of Egyptian priests, think about their predictive algorithms as of ancient sacred formulas - and you will get a picture of what is happening in the world right now, with the difference that modern tools have become much more pervasive and sophisticated, and they are being applied not to natural phenomena, but to the social realm.

People have always dreamt about predicting the future. In Ancient Greece, the priestess named Pythia delivered prophecies in a frenzied state induced by vapors rising from the chasm, and her talks were interpreted as signs of the future. However, for centuries, due to its complexity and unpredictability, the social reality has largely evaded attempts of being understood, with the same clarity and predictability as laws governing natural phenomena. Despite the efforts of such thinkers, as Henri de Saint-Simon and Auguste Comte, to create, in the $19^{\text {th }}$-century, so-called "social physics," these attempts largely did not move beyond purely theoretical speculations up until the most recent years. Two big obstacles were in their way: the lack of relevant statistical data and the absence of calculating power to process it. Today, both these obstacles increasingly yield to the power of computer technologies. The more they enter our lives, the more data, which before went unrecorded, becomes available for computer analysis. Couple that data with clever algorithms of discovering patterns in it - and you will get an oracle that will tell you the future more accurately than any Pythia of the past. This time based on science, not magic.

The word "algorithm" comes from Arabic and means "a procedure for solving a mathematical problem in a finite number of steps" (Merriam-Webster, Algorithm). While in the past it was a purely mathematical term, today its application has moved beyond science and technology. Decisions in such spheres, as business, finance, insurance, education, employment, healthcare, etc., increasingly become automated, especially at the grassroots level. While in the past decisions, such as: Whom to hire? What to advertise? How much to charge for insurance? were made by humans, now they are increasingly delegated to machines. The more we interact with them, the more relevant become the ethical questions: What type of society do they produce? Moreover, how does this novel social reality affect freedom? Let me deal with both questions, starting with the first.

Lewis Mumford, a prominent American historian of technologies, argued that the structure of society is consistent with the workings of its basic technology. He referred to the ancient hydraulic civilizations, as well as the $20^{\text {th }}$-century industrial superpowers, as "megamachines", or machines using humans as their components (Mumford, 1966, p. 312). According to 
Mumford, their social structure, including a hierarchical chain of command, immense bureaucracy, and social conformity, was rooted in their major technologies - first, centralized irrigation systems and, later, integrated industrial production.

This approach allows to suggest that modern society may also be consistent with its basic technology - the computer. The computer is basically a data conversion machine. Its processor takes a stream of "ones" and "zeros" from RAM, converts it into another stream via its microarchitecture - an intricate set of "logic gates," made of transistors performing Boolean operations ("AND", "OR", "NOT"), - and writes it back into RAM. Then the cycle repeats. From this viewpoint, automatic decision-making algorithms may be described as social counterparts of computer "logic gates." They also take data inputs - digitized information about human activities - and transform them into outputs (decisions). On the abstract level, they work as switches, which convert data flows. Just as a computer's "logic gate," which labels data inputs as "true" or "false," ADMAs do the same with information about individuals, which they sort into different types of binary categories: "accept/decline", "pardon/punish", etc.

Gilles Deleuze conceptualized a society, organized around switches and data flows, as the "Society of Control". He argued that individuals in the Society of Control become "dividuals", or double entities, consisting of their physical bodies and their representations in the system of computerized control, or the "code". This system automatically gives or blocks access to certain locations, opportunities, venues, etc., based on the code (Deleuze calls this computer-mediated environment "a variable geometry") (Deleuze, 1992, p. 4). The switches, thus, manage society in the same way, as electrons are managed inside the array of computer microchips. $\mathrm{He}$ exemplifies this as follows: "Félix Guattari has imagined a city where we would be able to leave one's apartment, one's street, one's neighborhood, thanks to one's (dividual) electronic card that raises a given barrier; but the card could just as easily be rejected on a given day or between certain hours; what counts is not the barrier but the computer that tracks each person's position - licit or illicit - and effects a universal modulation" (Deleuze, 1992, p. 7).

According to Deleuze, the Society of Control should be regarded as a novel type of power, because the concept of "disciplinary power" elaborated by Michel Foucault and its crucial element - the panopticon, - in his opinion, can no longer explain its workings in the digital age. ${ }^{4}$ In Foucault's theory, power was embodied in the panopticon, which can be generally described as a circular building with transparent cells along the perimeter and a central tower with an invisible watchman. This architectural design could be applied to all kinds of institutions, in which power was exercised over individuals, such as prisons, barracks, schools, factories, etc. The relations of power were born from its internalization because Foucault believed that internees of such institutions would perform their duties automatically even if nobody was watching them at any moment. He called the panoptic power "disciplinary," because its raison d'être was not to punish, as in the medieval "sovereign" type of power, but rather to train humans to become docile and useful beings.

Deleuze argues that since the late $20^{\text {th }}$ century "we are in a generalized crisis in relation to all the environments of enclosure - prison, hospital, factory, school, family" (Deleuze, 1992, p. 3 ). In order to exercise power in the $21^{\text {st }}$ century, there is a less need for prisons, labor camps, barbed wire, machine guns, and all those "heavy" institutions and tools, which were the symbols of power in the previous century. Today, power also works through switches and is exercised over data. The panoptic surveillance of bodies is supplemented by the surveillance of data, or "dataveillance," as Roger Clarke has suggested (Clarke, 1988), whereby a person's data is "imprisoned" in the database and used to control him from there. Those who oversee those switches, including governments, banks, and big tech companies, command authority over

\footnotetext{
${ }^{4}$ In Foucault's theory, the disciplinary power was itself historically discontinuous with the previous mode of "sovereign" power.
} 
individuals in a similar fashion as a computer user makes electrons inside his PC to perform useful computations.

This ecosystem of computerized control has progressed rapidly over a few decades and left liberal democracy totally unprepared for these new challenges. According to Yuval Noah Harari, classical liberalism has developed "an impressive arsenal of arguments and institutions to defend individual freedoms against external attacks from oppressive governments and bigoted religions, but it is unprepared for a situation when individual freedom is subverted from within, and when the very concepts of 'individual' and 'freedom' no longer make sense" (Harari, 2018). The "subversion of freedom from within" can be interpreted as the replacement of an individual - a sovereign and autonomous decision-maker - with an aggregation of data in the system of computerized control, in which clever algorithms discover patterns and make decisions about that individual in advance, without his approval or even knowledge, thus, handling him as a sort of raw material. This tends to push into seignioral relationships, since the value of the Other is denied, and he is treated more as a means than an autonomous end. I find "subversion" to be the proper word to describe this process, because, as the Society of Control develops, the loss of freedom comes not as an obvious, one-time political catastrophe, a head-on collision with some inner or outer political enemy, but as a silent, invisible, and stepby-step impairment, which circumvents the capacity of traditional political institutions to protect it.

The forces that, in Harari's words, "subvert freedom from within" come not so much from the government, but rather from the society itself, therefore, the challenges they pose to freedom should be understood less as a political, and more as an ethical issue (despite it may be needing a political response). Of course, governments actively partake in the collection of data about their citizens and use that data to control them algorithmically, as Edward Snowden showed the world in 2013, but, according to Shoshana Zuboff, these tactics were pioneered by private companies, including Google, Facebook, and Amazon. According to Zuboff, these companies invented a historically unprecedented business strategy, which mines personal information and turns it into profit. She calls this strategy "surveillance capitalism" and argues that Google is its "pioneer, discoverer, elaborator, experimenter, lead practitioner, role model, and diffusion hub" (Zuboff, 2020, ch. 3). In many ways, the private sector is ahead of many governments in the collection of data about individuals and the invention of intricate ways of controlling them algorithmically. Perhaps, the biggest scandal around the application of digital algorithms for political purposes involved a private company - the British political consulting firm Cambridge Analytica.

All those rights that have been won in long historical struggles in the "physical" world are not automatically protected online. The digital realm, which, in the early days of the Internet, was seen as a space of anonymity and freedom, is now increasingly being claimed by rapacious corporations and power-greedy governments as a realm of one-sided and unchecked power. This is reminiscent of the colonial age when Western countries discovered huge territories overseas and began exploiting them because the rights their citizens enjoyed at home were not extended there, and private companies were often among the biggest exploiters. Now, the "territory" to be exploited is located not in the physical world, but in the parallel world online, while what is being exploited is not natural resources, but the personal information of Internet users.

In the preceding part of the article, I outlined the distinction between "good" and "bad" types of power. The former (social) power is based on the value of freedom and treats its subjects as autonomous ends, while the latter (seignioral) regards them as pure means. The power exercised by ADMAs, which have been designed primarily to spare costs and optimize useful output, is seignioral. Insurers, banks, and other bodies install them to cut losses and maximize profit. In this way, their role is like that of Michel Foucault's panopticon. Like the panopticon, ADMAs 
divide their subjects into a double mode: normal/abnormal, compliant/non-compliant, efficient/inefficient, etc., and thus, exercise a "normalizing gaze." They also serve the panoptic function of "strengthening social forces - increasing production, developing the economy, spreading education, raising the level of public morality" (Foucault, 1995, p. 208). Foucault interpreted the panopticon as a "diagram of a mechanism of power reduced to its ideal form" (Foucault, 1995, p. 205). An ideal panopticon is $0 \%$ freedom and $100 \%$ power. Panoptic power is also completely asymmetrical - its internees have no capacity to challenge the power, which has been unilaterally imposed on them and made them mere means to their master's ends. The parallels with the panopticon allow us to argue that the ecosystem of ADMAs increases the "bad" type of power, or the one that benefits its carriers at the cost of its subjects, and, thus, damages freedom. How exactly does this happen? So far, we have considered the ethical value of freedom and the unprecedented social order that is based on data flows and automatic switches. Let us now examine several ways how it affects freedom and what ethical issues may arise herewith.

\section{The Goliath of the microchip}

Sarah Wysocki was a schoolteacher from Washington DC. In 2009, the city's municipal authority decided to reform its school system and dismiss low-performing teachers. For this purpose, it harnessed a software named IMPACT, which evaluated teachers' performance based on their students' progress in math and language tests in two consecutive years. A complex algorithm had to separate the teacher's output from a variety of other factors. Wysocki thought she did not have to worry because her students and their parents rated her highly as a teacher. However, she was eventually fired because IMPACT gave her an implausibly low score. Though she understood that the score was unfair, it was not easy to prove. Neither the school administrators, nor the education officials knew how the algorithm worked, but they all appealed to a fair and unbiased judgment of the machine. Wysocki hypothesized that, perhaps, her students' previous scores had been artificially bloated and that led to her poor evaluation as a teacher. Eventually, her case received media attention and she was hired by another school. Her case, however, leaves open the question: How many other people have been unfairly punished under the same circumstances?

The story of Sarah Wysocki summarizes many features of ADMAs. First, they are unilaterally imposed upon individuals, often without their consent, and used to measure their value as workers, borrowers, customers, etc. Second, the inner mechanisms of these systems are often shrouded in mystery. Few people, except for their creators, ${ }^{5}$ can tell how the algorithms arrive at their conclusions. Third, they make a probabilistic assumption that a person might be an inefficient worker or untrustworthy borrower, but that person ends up being treated as if he/she is such a person. A bad credit history or prolonged unemployment will aggravate their situation even further and eventually catch them in a vicious feedback loop, whereby the score damages their life, and vice versa. This potentially can foster an unequal society, in which the poor will be destined to remain so forever. The mathematician Cathy O'Neil calls these algorithms 'weapons of math destruction' and discusses them as follows:

Many of the 'weapons of math destruction' behave like that. They define their own reality and use it to justify their results. This type of model is self-perpetuating, highly destructive - and very common. [...] An algorithm processes a slew of statistics and comes up with a probability that a certain person might be a bad hire, a risky borrower, a terrorist, or a miserable teacher. That probability is distilled into a score, which can turn someone's life upside down. And yet when the person fights back, 'suggestive'

\footnotetext{
${ }^{5}$ In the case of self-trained AI, even the creators of those systems won't be able to tell how they arrive at their conclusions.
} 
countervailing evidence simply won't cut it. The case must be ironclad (O'Neil, 2018, intro).

The researcher Frank Pasquale argues that a new social phenomenon arises from the ubiquitous use of opaque algorithms, like IMPACT. He calls this phenomenon a "black box" society and emphasizes the double definition of the term "black box," which means both a recording device and something mysterious, impenetrable to scrutiny. Pasquale summarizes the features of "black box" society as follows. First, they set "a rule of scores and bets." A person's life is distilled into a score and is measured thereof, while giving little power to control or even know how the score is calculated. Second, these algorithms create "separate and unequal economies," since the scores tend to punish the poor and favor the rich. ${ }^{6}$ Third, they produce "invisible powers." While there is a demand that democratic power should be maximally transparent, "black box society" is a significant setback from this demand. Fourth, the algorithms set up "wasteful arms races and unfair competitions." Pasquale illustrates this statement with Gary Shteyngart's dystopian novel Super Sad True Love Story, in which its characters did not care about what the scores meant or how they were calculated - they only wanted high ones (Pasquale, 2016, p. 190).

The first ethical challenge to freedom in the Society of Control that I would discuss in this article involves its negative dimension, namely privacy. The researcher Alan F. Westin argues that the connection between freedom and privacy is rooted in territoriality, or the inherent desire of most animals to keep and defend their territory. If we understand negative freedom as a state of protection from unwanted intrusion, privacy goes hand in hand with it. For humans, according to Westin, privacy includes not only their physical surroundings, but also the abstract spheres of mind and relationships. He defines privacy as "the claim of individuals, groups, or institutions to determine for themselves when, how, and to what extent information about them is communicated to others" (Westin, 1970, p. 7). While privacy is equivalent with freedom, surveillance, on the other hand, is synonymous with power. The inmates of the panopticon were stripped of any private corner to hide from the all-seeing, judgmental eye of the watchman.

ADMAs rely heavily on surveillance. In order to work, they need data. The more data they have, the more accurate are their calculations and predictions. The desire to improve accuracy, thus, runs against the social demand for privacy and, ipso facto, freedom. Michael Karanicolas provided, perhaps, the best illustration of the intrusion into privacy:

Imagine a typical day you spend strolling through a shopping center in your hometown. Perhaps you will browse through titles at a bookstore or record shop, visit your bank or take in a movie. You may see friends or acquaintances and stop to catch up. Now imagine that, for the entire day, there was a group of people following you, diligently writing down every shop you visited and object you looked at and every person you spoke to. Imagine they collated that information to build as detailed a profile as possible about you: your demographic and income level, your hobbies and interests, your political beliefs and so on. Imagine they spent months or years collecting the information, and then offered it for sale to anyone who was interested (Karanicolas, 2014, p. 7).

In the Society of Control, human lives progressively become open books. Cameras record how they drive and where they go. Their browsing history and shopping habits reveal intimate details about their health and lifestyle. All that data is assembled into their digital profiles and treated as raw material for algorithmic calculations. "There are now hundreds of credit scores for sale," writes Frank Pasquale, "and thousands of 'consumer scores,' on subjects ranging from frailty

${ }^{6}$ O'Neil puts forward the same argument: "The privileged are processed more by people, the masses by machines" (O’Neil, 2016, intro). 
to reliability to likelihood to commit fraud. ChexSystems and TeleCheck track bounced checks; Alliant Cooperative Data Solutions documents missed monthly payments for gym memberships; payday lenders report 'deadbeats' to Teletrack. Datalogix has lists of dieters. And there are far more sources of data for all these scores than there are scores themselves" (Pasquale, 2016, p. 33). He adds that any of these scores "could change our lives on the basis of a falsehood or a mistake that we don't even know about" (Pasquale, 2016, p. 33). The complexity of those systems is an effective shield against scrutiny and accountability.

As a state of protection from unwanted intrusion, negative freedom can be regarded as its "passive" part. Positive freedom, or the ability to maintain control over one's life and achieve one's goals, is rather the "active" part of freedom. I can claim to have positive liberty if it is $m e$ - not somebody else - who makes decisions about my life. Of course, my boss can fire me anytime or my country can put me in prison. If this happens because I broke some of the rules, to which I had voluntarily agreed, this is fair. ${ }^{7} \mathrm{I}$ am still in charge of my fate because I can decide anytime whether to follow those rules or not.

In the Society of Control, positive freedom can mean three things: i. to oversee what data is assembled about me, by whom, and under what circumstances; ii. to control or, at least, understand how this data can be used to make decisions about me; iii. to be able to challenge those decisions if there is a suspicion that they are unfair. The case of Sarah Wysocki demonstrates that all three assumptions have been violated. She could neither control the collection of data, nor did she know how the system came up with the score or could effectively challenge it. In 2011, the press discussed the case of an Arkansas resident named Catherine Taylor who had trouble finding employment for several years (O’Neil, 2016, ch. 8). After many failures to find a job, she discovered that another Catherine Taylor, who happened to be born on the same day, had a criminal record. Her prospective employers checked her name in the database and got the answer that she was a former convict. Taylor managed to clear out that record, but it had already been copied into many other consumer databases, and, perhaps, she is still being treated as a criminal. Her case shows how one's life can be tethered to one's digital profile and illustrates the argument: "We do not produce our databased selves, the databased selves produce us" (Chesterman, 2018).

While Taylor's case demonstrates how a single mistake in the system of computerized control can turn one's life upside down, the case of a youth named Kyle Behm shows how one can be harmed due to a lack of knowledge of how the system works. Behm was a college student who suffered from bipolar disorder. After rehabilitation, he was looking for a low-income job but was constantly "red-lighted" by his prospective employers. Kyle found that the reason behind his misfortunes was a single computer test that the employers in his hometown were using. This test was developed by Kronos, a workforce management company from Boston, Massachusetts, and measured a prospective employee's performance based on the five-factor personality model (O'Neil, 2016, ch. 6). Since it is illegal to use health records or IQ scores in employment in the United States, the companies have found a proxy for them in a seemingly harmless personality test. A common feature of such tests is that their takers never know what answers may disqualify them. For example, McDonald's asks its prospective workers to choose which of the following answers describe them better: "It is difficult to be cheerful when there are many problems to take care of" or "Sometimes, I need a push to get started on my work" (O'Neil, 2016, ch. 6). It can be only guessed which answer is worse. In fact, there are no "right" answers whatsoever, because the computer collates the test-takers' answers with their future performance at work and discovers patterns, which "red-flag" an applicant if he unluckily falls into one of them. The decision is not even made by a person.

\footnotetext{
${ }^{7}$ The consent and moral obligation of a citizen to obey his country's laws are presumed in the theory of social contract (Carmichael, 1989, pp. 949-950).
} 
The defenders of such tests argue that if their rules were revealed, the takers would "game" the system by choosing only the appropriate answers but this also creates a Kafkaesque situation when someone is judged by the rules that are hidden from him. "A bad credit score may cost a borrower hundreds of thousands of dollars, but he will never understand exactly how it was calculated," writes Frank Pasquale. "A predictive analytics firm may score someone as a "high cost' or 'unreliable' worker, yet never tell her about the decision" (Pasquale, 2016, p. 5). The practice of judging someone by hidden rules seems to be unprecedented in history. Historically, people have been judged by norms, which were fair or unfair, permissive or oppressive, just or discriminatory, but they had one thing in common: in all cases, they were revealed to their subjects. One could decide whether to follow or break those rules and, thus, maintain some degree of control over one's life even under the most oppressive political regimes. In the Society of Control, on the contrary, the rules progressively become hidden. Its members are reminded of the Biblical workers in the Vineyard (Matthew 20:16): the punishment can come anytime, but they do not know when and from where to expect it. Imagine a Kafkaesque scenario: In the dystopian future, society is fully ruled algorithmically. One day a police officer may knock on your door and say that a computer program has decided that you are a bad citizen and should be prosecuted, however neither he, nor anyone else will tell you why. In such a society, human life will depend on some inscrutable external force, which will also effectively invalidate resistance. Indeed, how can one revolt against something that he does not even understand? Now, we see only the early forebodings of such a future. But what can ultimately prevent this grim fantasy from coming true? If somebody had told Europeans in the early 1910s what was to befall them in the next 30 years, they, probably, would have called him a madman.

Another ethical challenge to freedom comes from ADMAs' blindness to social contexts. For example, an MIT study found that it was possible to predict a person's sexual orientation by analyzing their friends on Facebook (Heussner, 2009). With this clue, users can be targeted with LGBT content. One user who did not openly disclose his sexual orientation found a rainbow-emblazoned ad for "Coming out Coach" on his Facebook page (Pasquale, 2016, p. 26). It can be imagined what would happen if this user lived in one of those countries where homosexuality is punishable or heavily stigmatized. In a widely discussed case, the US supermarket chain Target invented an algorithm that predicted pregnancy by analyzing the shopping behavior of its female customers. With this algorithm, they began sending ads with baby products to women who they believed were pregnant. It turned out that they unwittingly disclosed one girl's pregnancy to her family without her consent (Kashmir, 2012). It is obvious that reckless dealing with such intimate details of life can often be disastrous. These cases demonstrate how socially blind ADMAs make it harder for individuals to control their privacy and, eventually, their lives.

Western societies have fought a long way to reduce social stigmas around, for example, gay people or the disabled. New stigmas, however, seem to appear in the Society of Control. If an algorithm identifies someone as lazy or unreliable, this person may face a snowball effect throughout his entire life. Even if such identification is occasionally true, it will still block his attempts to improve his life and turn over a new leaf - something we inherently associate with freedom. In the past, if someone were fired for carelessness, he could apply elsewhere. Now, his name will probably end up in a database and tarnish his life forever. "Since the beginning of time," writes the researcher Victor Mayer-Schönberger, "for us humans, forgetting has been the norm and remembering the exception. Because of digital technology and global networks, however, this balance has shifted. Today, with the help of widespread technology, forgetting has become the exception, and remembering the default" (Mayer-Schönberger, 2009, p. 2). Freedom in the digital age is incomplete without what seems to be a new human right - the right to be forgotten. 
The examples of Catherine Taylor, Kyle Behm, and the anonymous pregnant girl can all be interpreted in the context of reductionism, which is a philosophical concept for scaling down a complex phenomenon to its basic parts and endowing it with the same value as those parts. An example of reductionism can be found among the ideas of several philosophers-materialists of the Enlightenment who argued that physical matter, governed by the laws of mechanical motion, was the only true form of existence, and regarded human beings as just another form of it. Julien Offray de La Mettrie's L'Homme Machine [Machine man] (1747) is a classic example of this approach. A society made of such "machine men" would not have moral status and would be just raw material for social experimentation. The infamous phrase by Josef Stalin: "Forest chopped - chips fly," in which he compared human beings to lumber, can serve as an iconic example of reductionism.

In the Society of Control, human beings face a different kind of reductionism. They are reduced not to physical matter, as in the Communist or Nazi totalitarian regimes, but to another sort of raw material - data. A computer does not care if its data inputs are about schoolteachers, disabled persons, low-income workers, marginalized social groups, stock market assets, earthquakes, atmospheric winds, or oxygen on Mars - it will process them equally. The companies attempt to "datafy" human lives and approach them as a mathematical problem to be solved; but what on the surface may seem like solving a technical problem, ignores the fact that there are human lives and destinies chained to the pieces of data inside the computer processor. As Shoshana Zuboff has put it, "Each rendered bit is liberated from its life in the social, no longer inconveniently encumbered by moral reasoning, politics, social norms, rights, values, relationships, feelings, contexts, and situations. All things animate and inanimate share the same existential status in this blended confection, each reborn as an objective and measurable, indexable, browsable, searchable 'it'" (Zuboff, 2020, ch. 7). Although Zuboff did not use the terms from Rosmini's ethical vocabulary, it is apparent that this process reinforces the seignioral relationships. As she writes, "users were no longer ends in themselves but rather became the means to others' ends" (Zuboff, 2020, ch. 3).

Vertical social mobility, or the ability to climb the social ladder and uplift one's status in the eyes of peers, is another integral part of freedom. For this reason, ancient hierarchical societies, whose members were fixed to their social roles throughout their lives, are widely regarded as unfree from the modern standpoint. The "pursuit of happiness" is never complete without the aspiration for a higher status. However, ADMAs tend to undermine this natural human right by creating pernicious feedback loops, which tether a person to his initial social position and work against his struggle to improve it. For example, when an algorithm evaluates someone as "unreliable," this person, probably, will not be hired and the longer they stay without a job, the lower their employment score and, therefore, chances to get one in the future. Cathy O'Neil argues that these vicious feedback loops are especially subversive for those at the bottom of society. "The poor are expected to remain poor forever and are treated accordingly-denied opportunities, jailed more often, and gouged for services and loans. It's inexorable, often hidden and beyond appeal, and unfair," she writes (O’Neil, 2016, ch. 8). In her book Weapons of Math Destruction, she discusses several examples of how algorithms tend to create such loops.

For example, in Reading, Pennsylvania, the local police department employed an algorithm named PredPol, which processes historical crime records and predicts in which areas of the city crimes are more likely to occur around certain hours. These areas then become primary targets for police patrols. According to O'Neil, this algorithm has a major flaw: more police means more recorded crimes, especially petty ones, which, in turn, justify further policing. Eventually, some areas become overpoliced. In the US, according to O'Neil, those areas tend to overlap with segregated minority neighborhoods, making them targets of disproportionate police scrutiny (O'Neil, 2016, ch. 5). This not only reinforces racial divisions, but also increases the chances of police brutality, such as happened to George Floyd on May 25 2020. 
Another example of toxic feedback loops from O'Neil's book involves predatory advertising strategies aimed primarily at people in desperate need. Rapacious companies use algorithms to navigate through the personal information of Internet users and pinpoint the most vulnerable ones. People often unwittingly disclose their weak points when they browse or fill in online questionnaires. These people are targeted with dubious ads, which promise a miraculous cure for their problems, such as payday loans or crooked medication, but eventually drive them even further into need. O'Neil quotes one for-profit college named the Vattertott University, which advertises its services to the following social categories: "Welfare Moms with kids. Pregnant Ladies. Recent Divorce. Low Self-Esteem. Low Income Jobs. Experienced a Recent Death. Physically/Mentally Abused. Recent Incarceration. Drug Rehabilitation. Dead-End Jobs-No Future" (O'Neil, 2016, ch. 4). Preying on the vulnerable has been out there for millennia, but in the age of Big Data and sophisticated algorithms, it can be carried out with unprecedented speed and precision.

What ADMAs do with social status, they also do with information. Possessing true information is an epistemological part of freedom. Nobody is free unless he acts based on true and objective knowledge. The connection between freedom and truth was famously established in the Bible: "And ye shall know the truth, and the truth shall make you free" (John 8:32). However, search engines and social media websites use algorithms, which "predict" what kind of content their users will most likely consume based on the history of their searches. This means that if someone has illusions, he will get stuck in the bubble of these illusions. Here again, one's past is automatically projected into the future and decisions are being made about him, not by him. Tom Steinberg, a British author, provides a vivid illustration of this phenomenon:

I am actively searching through Facebook for people celebrating the Brexit leave victory, but the filter bubble is SO strong, and extends SO far into things like Facebook's custom search that I can't find anyone who is happy despite the fact that over half the country is clearly jubilant today and despite the fact that I'm actively looking to hear what they are saying. This echo-chamber problem is now SO severe and SO chronic that I can only beg any friends I have who actually work for Facebook and other major social media and technology to urgently tell their leaders that to not act on this problem now is tantamount to actively supporting and funding the tearing apart of the fabric of our societies... We're getting countries where one half just doesn't know anything at all about the other (Viner, 2016).

Plato famously described prisoners in a cave who could see nothing but the shadows of things. By chaining individuals to their habitual ways of looking at things, ADMAs breathe new life into this ancient metaphor.

From their onset, IT promised liberation. At least, it was the vision of Californian Ideology and its early adepts who combined entrepreneurial zeal with the counter-cultural stance of the 1960s and loathed any form of oppression. Ronald Reagan famously said that "the Goliath of totalitarianism will be brought down by the David of the microchip." Now, however, there seem to be Goliaths with the microchip. The Society of Control has the potential to become a new page in the long catalog of oppressive regimes. Paraphrasing Marx, the underdogs of the future will have nothing to lose but their scores and database records.

\section{Conclusion}

Michel Foucault was one of the most insightful thinkers who studied the historical evolution of power. In his significant philosophical heritage, he mostly examined the transition from "sovereign" power, which involved obedience to the central authority figure with the right "to take life or let live," to what he called "disciplinary" power, embodied in the panopticon. The 
panopticon was a multi-purpose space of enclosure, surveillance, and coercion for all types of applications - from overseeing prisoners to managing the workforce. According to Foucault, this technical invention helped to establish a vast network, or "microarchitecture," of power, coextensive with the entire social body. Individuals in such a society moved from one space of enclosure to another, for example from school to factory, and lived under life-long surveillance, which trained them to become useful, docile, and compliant beings.

Disciplinary power reached its height in 20th century totalitarian regimes. When Foucault analyzed its workings, a new mode of power was already lurking on the horizon underpinned by emerging computer technologies. His premature death in 1984 prevented him from formulating a schema of it as comprehensive as the panopticon. This task was completed by Gilles Deleuze who developed the concept of the Society of Control in 1992. Power in this society is focused on the management of data in computerized networks and databases. This management is executed by automated switches, or algorithms, which modify the flows of data in electronic circuits, based on their instructions and protocols. Such a society resembles a computer, in which individuals correspond to electrons moving through a vast network of constantly changing switches. In this article, I have called these switches "automated decisionmaking algorithms" (ADMAs) and scrutinized mostly their impact on freedom.

As I stated in the first part of the article, such movements as Black Lives Matter allegedly indicate liberation and the defeat of seigniory. However, in the background of this asserted liberation there is the outgrowth of the Society of Control with its new mode of power, embodied in networks and switches. So, what is our age about - liberation or subjection? Or, maybe, both at once, like the Enlightenment, which created both the magnificent slogan "Liberté, Égalité, Fraternité" and the panopticon? Foucault himself emphasized this dialectical dichotomy when he contrasted "an explicit, coded and formally egalitarian judicial framework" with all those "tiny, everyday, physical mechanisms," which were "essentially non-egalitarian and asymmetrical" and "constituted the other, dark side of these processes" (Foucault, 1995, p. 222). It frequently seems that freedom is subject to the law of communicating vessels: if more of it is added in one place, the equal amount is reduced in another. However, reflecting on the intellectual heritage of the Enlightenment, it can be concluded that sometimes the mechanisms of power can break loose and engulf the whole society. This happened in 20th century totalitarian regimes, which applied the principles of the panopticon (no rights, universal surveillance, ubiquitous discipline, etc.) to the entire social body.

This leads me to the final question: What can prevent the Society of Control from following the same path? Today, China is experimenting with a comprehensive system of digital governance, named the Social Credit System, in which a person's life is distilled into a score used to mediate his status. But there are also reasons to worry in the West. In 2020, worldwide quarantine has shifted many human activities into the digital realm, potentially giving a big boost both to the volume of data circulating online and the means of its algorithmic processing. Simultaneously, some human rights, including the right to privacy, can be curtailed under the justification of fighting the virus. Some political thinkers already predict the end of democracy and welcome the advent of this "brave new world." However, if freedom has value, it must be saved. Since the return to the analog age is neither desirable, nor possible, let me suggest a few principles, which potentially may allow combining the benefits of technology with the fruits of freedom.

It is necessary to emphasize, though, that the proposed suggestions do not constitute a simple remedy or "silver bullet" that could solve the ethical threats posed by ADMAs. I believe that the solutions might exist in a complex interplay between technological, economic, social, and political aspects of the future of information society, which it is too early to anticipate. By way of analogy, it took decades for mankind to find remedies against the brutalization of nature and human labor in early industrial capitalist economy. In many ways (e. g., ecological 
damage), we are still facing its dire consequences. In one thing, however, we can be sure: Awareness of the problem is the first step to recovery. Therefore, I fully agree with the respected reviewer of this article that its main goal is to outline the problem. I suggest these measures (although I am aware that they are simplified and superficial) mostly as an invitation for further discussion.

1) Privacy. Individuals should control themselves which bodies (except government institutions authorized by court) have access to their data and how they use it. The companies should obtain data about their clients only under their informed consent, which includes a. describing the proposed intervention; b. discussing alternatives; $c$. explaining risks and consequences. They also should not be allowed to transfer that data without their approval. Special attention should be drawn to the protection of minors and other vulnerable groups.

2) Oversight. Individuals should oversee what data is stored about them and to whom it is communicated, especially if it is related to sensitive issues, such as health, financial status, private life, religious and political views. Oversight by individuals should be complemented by government oversight. There is a need for a digital rights code, like codes regulating labor.

3) Ethical obligations. Any algorithm that decides about a human being should be approved by a special commission consisting of IT-specialists, lawyers, ethicists, and social scientists. If it affects millions of people, the authorization procedure should be as complex, strict, and multistage, as in the case of the country's laws.

4) Transparency. No judgment by opaque, "black box" algorithms is ethically acceptable. There should be a list of spheres, in which decisions can be made only by humans (for example, in criminal law) and a much wider list where automated systems can only assist humans. Only where the public benefit clearly outweighs risks, there can be fully autonomous systems. However, even there, a person should always be able to know how the system came up with the result and challenge it before a human being.

5) The right to be forgotten. The capacity of digital networks to store information virtually forever brings into the spotlight the discussion about a new human right - the right to be forgotten, or silence past events in one's life if they are no longer relevant. If it is a database record about some minor violation, the perpetrator should be able to redeem it, for example, by charity or community work (no excuse can be made for felons or repetitive violators). If these are publications about some blameworthy facts of his life, he should be able request their removal after a while (exceptions can be made for people who occupy important offices, felons, or if such facts are somehow important for society). A nuanced discussion is needed about how the right to be forgotten can be balanced against freedom of information.

The initial stage of the information age in some ways resembles the onset of the Industrial Revolution when humans mastered a new powerful technology, but still lacked a proper moral and legal attitude to it. When we look back at those times, we shudder at the pictures of child labor, pollution, and unbearable working conditions in the early factories. Perhaps future generations will have the same attitude to our times.

\section{References}

BERLIN, I. (1969): Four essays of liberty. Oxford. Oxford University Press.

CARMICHAEL, D. J. C. (1989): The consent theory of political obligation. In: Ethics, 99(4), pp. 949-950.

CHESTERMAN, S. (2018): Privacy and our digital selves. In: Simon Chesterman, September 5, 2018. [online] [Retrieved September 18, 2020] Available at: https://simonchesterman.com /blog/2017/09/02/our-digital-selves . 
CHOPRA, S. \& WHITE, L. (2011): A Legal Theory for Autonomous Artificial Agents. Ann Arbor: University of Michigan Press.

CLARKE, R. (1988): Information technology and dataveillance. In: Communications of the ACM, 31(5), pp. 498-512.

DELEUZE, G. (1992): Postscript on the Societies of Control. In: October, 59, pp. 3-7.

FOUCAULT, M. (1995): Discipline \& Punish. New York: Vintage Books.

HARARI, Y. N. (2018): The myth of freedom. In: The Guardian, September 14. [online] [Retrieved September 18, 2020] Available at: https://www.theguardian.com/books/2018/sep/ 14/yuval-noah-harari-the-new-threat-to-liberal-democracy?CMP=share_btn_fb

HEUSSNER, K. (2009): “Gaydar" on Facebook: Can your friends reveal sexual orientation? In: $A D C$ News, September 21. [online] [Retrieved September 18, 2020] Available at: https://abcnews.go.com/Technology/gaydar-facebook-friends/story?id=8633224

KARANICOLAS, M. (2014): Travel guide to the digital world: Surveillance and international standard. London: Global Partners Digital.

KARAS, A. (2003): Filosofiia hromadianskoho suspilstva $v$ klasychnykh teoriiakh $i$ neklasychnykh interpretatsiiakh [The philosophy of civil society in classical theories and nonclassical interpretations]. Kyiv \& Lviv: Ivan Franko University Press.

KASHMIR, H. (2012): How target figured out A teen girl was pregnant before her father did. In: Forbes, February 16. [online] [Retrieved September 18, 2020] Available at: https://www.forbes.com/sites/kashmirhill/2012/02/16/how-target-figured-out-a-teen-girl-waspregnant-before-her-father-did/\#66c1d8466668

KASTRUP, B. (2020): Yes, free will exists! In: Scientific American, February 5. [online] [Retrieved September 18, 2020] Available at: https://blogs.scientificamerican.com/ observations/yes-free-will-exists/

MAYER-SCHÖNBERGER, V. (2009): Delete: The virtue of forgetting in the digital age. Princeton, NJ: Princeton University Press.

MILL, J. S. (1975): On liberty. New York: Norton.

MUMFORD, L. (1966): Technics and the nature of man. In: Technology and Culture, 7(3), pp. 303-317.

O'NEIL, L. (2016): Weapons of math destruction: How big data increases inequality and threatens democracy. New York: Crown. [online] [Retrieved September 18, 2020] Available at: http://governance40.com/wp-content/uploads/2019/03/Weapons-of-Math-DestructionCathy-ONeil.pdf

PASQUALE, F. (2016): Black box society: The secret algorithms that control money and information. Cambridge, MA: Harvard University Press.

ROSMINI, A. (2010): Philosophy of Politics, vol. II. Durham: Rosmini House.

SAINATO, M. (2015): Stephen Hawking, Elon Musk, and Bill Gates warn about artificial intelligence. In: Observer, August 19. [online] [Retrieved September 18, 2020] Available at:

https://observer.com/2015/08/stephen-hawking-elon-musk-and-bill-gates-warn-aboutartificial -intelligence/

VINER, K. (2016): How technology disrupted the truth? In: The Guardian, July 12. [online] [Retrieved September 18, 2020] Available at: https://www.theguardian.com/media/2016 /jul/12/how-technology-disrupted-the-truth

WESTIN, A. (1970): Privacy and freedom. New York: Atheneum.

ZUBOFF, S. (2020): The age of surveillance capitalism: the fight for a human future at the new frontier of power. New York: PublicAffairs. [online] [Retrieved September 18, 2020] Available at:

https://we.riseup.net/assets/533560/Zuboff\%2C+Shoshana.The+Age+of + Surveillance + Capita lism.2019.pdf 